\title{
INFLEKSI DALAM BAHASA BANJAR
}

\author{
Akhmad Humaidi, Kamariah, dan Haswinda Harpriyanti \\ STKIP-PGRI Banjarmasin \\ Jln. Sultan Adam Kompleks H. Iyus, No. 18 RT. 23 Banjarmasin, \\ Kode Pos 70121. \\ e-mail: humaidi.a@stkipjm.ac.id
}

\begin{abstract}
Abstrak
Penelitian mengenai infleksi dalam kepustakaan modern telah dilakukan pada berbagai bahasa. Bahasa Banjar sebagai lingua franca di sebagian besar wilayah Kalimantan perlu mendapat perhatian yang sama di bidang ini. Penelitian ini bertujuan untuk mendeskripsikan infleksi bahasa Banjar dalam lingkup verba, nomina, dan adjektiva. Metode yang digunakan ialah observasi. Sumber data utama penelitian ini berbentuk tulisan yang diambil dari berbagai sumber dokumen berbahasa Banjar. Penelitian ini menemukan dalam bahasa Banjar pada lingkup verba, prefiks infleksi berjumlah 5 buah, yaitu $m a-, d i-, b a-$, $t a-$, dan $s a$-, infiks 4 buah, yaitu -ar-, -ur-, -al-, dan -ul-, sufiks 1 buah, yaitu -akan, sedangkan konfiks berjumlah 6 buah, yaitu ma-an, ma-i, ma-akan, taan, ta-i, dan ta-akan, serta imbuhan gabung 2 buah, yaitu mai-i-akan dan ta-i-akan. Pada lingkup nomina, prefiks infleksi berjumlah 2 buah, yaitu $p a$ - dan $s a$-, sedangkan konfiks berjumlah 3 buah, yaitu sa-an, ka-an, dan pa-an, sedangkan imbuhan gabung 1 buah, yaitu sa-an-nya. Pada lingkup adjektiva, prefiks infleksi berjumlah 3 buah, yaitu $m a-, t a-$ , dan $p a$-, sufiks 1 buah, yaitu -an, dan konfiks berjumlah 4 buah, yaitu sa-an, pa-an, pa-nya, dan ka-an.
\end{abstract}

Kata Kunci: infleksi, bahasa Banjar

\section{Pendahuluan}

Bahasa Banjar telah lama digunakan sebagai lingua franca bukan hanya di daerah asalnya, tetapi juga di sebagian wilayah di luar Kalimantan Selatan. Hapip (2008: 2) menyebutkan bahwa bahasa Banjar menjadi bahasa antaretnis, misalnya antara Dayak dan Jawa atau Bali terutama dalam transaksi jual beli di pasar-pasar. Bahasa ini juga digunakan di provinsi Kalimantan Timur seperti di Tanah Grogot, Balikpapan, Samarinda, bahkan Tarakan kota terbesar di Kalimantan Utara.

Morfologi menjadi salah satu persoalan yang harus dipahami oleh seseorang yang ingin mempelajari bahasa Banjar. Salah satu persoalan yang menarik di bidang ini ialah konsep infleksi. Pembahasan mengenai persoalan ini masih tergolong baru dalam kajian linguistik di Indonesia. Istilah infleksi akrab dipakai pada tradisi pemerian tata bahasa Yunani atau Latin Kuno dan juga pada bahasa-bahasa Indo-Eropa, tetapi kurang akrab dalam tradisi penulisan tata bahasa Indonesia atau bahasa-bahasa daerah di Indonesia.

Kajian tentang infleksi dalam bahasa Indonesia sebagai bahasa nasional pun baru ramai dibicarakan sekitar tahun 2006. Beberapa penelitian yang sudah dilakukan antara lain dilakukan oleh Purnanto (2006), Samingin (2006), dan Ermanto (2008). Sebenarnya, penelitian mengenai 
infleksi pada jurnal-jurnal internasional telah melampaui telaah metode tradisional dengan linguistik deskriptif. Beberapa kajian yang relevan antara lain ditulis oleh Kirkici \& Clahsen (2012: 776) dan Kim, Wang, \& Ko, (2011). Kajian infleksi dewasa ini mulai berkembang hingga bahasa-bahasa daerah di Indonesia. Beberapa di antaranya seperti bahasa Sunda (Riani, 2012), bahasa Kulisusu (Ramsi, 2017), bahasa Jawa (Widayanti, Wibisono, \& Sofyan, 2013), dan dialek Nusa Penida (Mantra, Budasi, \& Suarnajaya, 2013).

Hal ini menunjukkan bahwa kajian infleksi merupakan bidang yang menarik. Penelitian mengenai infleksi dalam kepustakaan modern telah dilakukan dengan melibatkan disiplin ilmu yang lebih luas. Kajian mengenai konsep ini dalam bahasa daerah di Indonesia perlu terus ditingkatkan. Sayangnya, penelitian mengenai infleksi dalam bahasa Banjar sepengetahuan penulis belum dilakukan. Oleh sebab itu, kajian ini penting dilakukan sebagai salah satu upaya untuk memetakan struktur bahasa Banjar.

\section{Metode}

Sumber data utama penelitian ini berbentuk tulisan. Teks tertulis diambil dari berbagai sumber dokumen berbahasa Banjar. Teknik yang digunakan ialah obervasi terhadap sumber data tertulis. Pengamatan difokuskan pada kata-kata yang mengalami proses infleksi.

Analisis ini dilakukan dalam tiga tahap utama, yaitu klasifikasi, analisis, dan penyimpulan. Tahap klasifikasi data meliputi pengumpulan data pada suatu kategori yang sama. Data-data yang telah diklasifikasi selanjutnya dianalisis berdasarkan sistem afiksasi, yaitu prefiks, infiks, sufiks, konfiks, dan imbuhan gabung. Analisis juga meliputi identifikasi data dan aspek semantiknya. Tahap penyimpulan berusaha memaparkan apa implikasi teoritis yang terkandung dalam konsep infleksi bahasa Banjar.

\section{Pembahasan}

Proses afiksasi tanpa disertai perubahan identitas kelas kata dalam morfologi dikenal dengan istilah infleksi. Kridalaksana (2011: 93) menyatakan infleksi adalah adalah perubahan bentuk kata yang menunjukkan berbagai hubungan gramatikal; mencakup deklinasi nomina, pronomina, dan ajektiva, dan konjungsi verba. Penelitian ini akan memaparkan afiks apa saja dalam bahasa Banjar yang bersifat demikian. Afiksasi ini mengubah makna kata dasar, tetapi kelas katanya tidak berubah. Oleh sebab itu, pembahasan akan berfokus pada aspek semantik kata yang mengalami proses infleksi.

Pembentukan infleksional dalam bahasa Banjar yang ditelaah dalam penelitian ini dibagi menjadi tiga, yaitu pembentukan infleksional dalam lingkup verba, nomina, dan adjektiva. Pembahasan mengenai persoalan ini adalah sebagai berikut. 


\section{A. Pembentukan Infleksional dalam Lingkup Verba}

Pembentukan infleksional pada lingkup verba dalam Bahasa Banjar melibatkan afiks yang paling banyak dibandingkan lingkup kelas kata yang lain. Pada penelitian ini, setidaknya ada 18 afiks yang tergolong infleksional. Penelitian ini menemukan prefiks berjumlah 5 buah, sufiks 1 buah, infiks 4 buah, konfiks 6 buah, dan imbuhan gabung 2 buah. Pembahasannya adalah sebagai berikut.

\section{Prefiks Infleksional Verba}

Prefiks infleksional dalam bahasa Banjar berjumlah lima buah, yaitu $m a-$, di-, $b a-$, ta-, dan $s a$-. Semuanya memiliki makna yang sangat mirip, yakni melakukan atau mengerjakan sesuatu. Afiks-afiks ini menegaskan kembali verba yang dilekatinya sebagai kata kerja aksi. Perbedaannya terletak pada posisinya dalam lingkup kalimat aktif dan pasif, kesengajaan, dan pengulangan.

Prefiks yang menegaskan verba sebagai kata kerja aksi terlihat pada $m a$ - dan $b a$-. Prefiks $m a$ - menghasilkan makna melakukan. Prefiks ini menegaskan makna dari kata dasar. Misalnya, kata tabuk bermakna gali. Setelah dibentuk dengan prefiks ma- menjadi menabuk yang berarti menggali atau melakukan aktivitas gali. Begitu juga manajak yang berasal dari ma + tajak yang berarti menancap.

Begitu juga dengan prefiks $b a$ - menghasilkan makna mengerjakan sesuatu. Contoh pembentukan ini dapat diamati pada teks berikut ini.

$$
\begin{array}{lll}
\mathrm{ba}+\text { gugur } & =\text { bagugur } & \text { (menjatuhkan diri) } \\
\mathrm{ba}+\text { tajak } & =\text { batajak } & \text { (mendirikan rumah) }
\end{array}
$$

Prefiks $d i$ - dalam bahasa Banjar juga menghasilkan makna melakukan sebagaimana prefiks $m a$ - dan $b a$-. Perbedaannya terletak pada posisinya dalam kalimat. Bila prefiks $m a$ - dan $b a$ - muncul pada kalimat aktif, prefiks $d i$ - muncul pada kalimat pasif. Contoh pembentukan ini adalah sebagai berikut.

$$
\begin{array}{lll}
\mathrm{di}+\text { tatak } & =\operatorname{ditatak} & \text { (dipotong) } \\
\mathrm{di}+\text { tabuk } & =\text { ditabuk } & \text { (digali) }
\end{array}
$$

Prefiks lain, yakni ta- juga menegaskan verba yang dilekatinya, tetapi makna yang dihasilkannya ialah tindakan itu terjadi tanpa sengaja. Pembentukan infleksional ini dalam bahasa Banjar dapat diamati pada contoh berikut ini.

$$
\begin{array}{lll}
\text { ta }+ \text { gugur } & =\text { tagugur } & (\text { terjatuh }) \\
\text { ta }+ \text { bulik } & =\text { tabulik } & \text { (kembali tanpa sengaja) }
\end{array}
$$


Prefiks infleksional yang terakhir, yaitu $s a$ - juga mengandung makna melakukan, tetapi bila kata dasar telah berbentuk reduplikasi, kemudian ditambah prefiks ini, makna yang muncul ialah tindakan berulang-ulang. Contoh pembentukan infleksional ini adalah sebagai berikut.

$\begin{array}{lll}\mathrm{sa}+\text { cabur } & =\text { sacabur-cabur } & \text { (menceburkan diri berulang-ulang) } \\ \mathrm{sa}+\text { bari } & =\text { sabari-bari } & \text { (memberikan berulang-ulang) }\end{array}$

\section{Infiks Infleksional Verba}

Infiks dalam bahasa Banjar cenderung tidak produktif. Infiks ini berjumlah terbatas dan jarang melekat pada kata-kata bahasa Banjar secara umum. Kemunculannya yang bersifat unik membuat generalisasi makna yang dihasilkan dari infiks ini agak sulit ditentukan. Infiks infleksional dalam bahasa Banjar berjumlah empat buah, yaitu -ar-, -ur-, -al-, dan -ul-.

Generalisasi yang dapat ditentukan terdapat pada infiks - ar-. Makna yang muncul ialah perbuatan yang dilakukan berkali-kali. Beberapa infiks - ar-dalam bahasa Banjar adalah sebagai berikut.
bubuy + ar
= barubuy
(siraman berkali-kali)
kucup + ar
= karucup
(kecupan berkali-kali)

Infiks yang lain cenderung unik dan setiap kata mengandung maknanya yang khusus. Beberapa kata yang berasal dari pembentukan infiks ini adalah sebagai berikut.
kambit + ur
$=$ kurambit
kikih + ur
$=$ kurikih

Kata kambit memiliki makna diikat atau dijahit. Setelah dibentuk oleh infiks -ur- menjadi kurambit yang bermakna menjahit baju yang kondisinya sudah rusak sehingga hasil jahitannya tidak rapi. Kata kikih bermakna mencari, kemudian setelah dibentuk oleh infiks -ur- menjadi kurikih yang bermakna mencari dengan teliti. Kata sambi setelah disisipi infiks - ur-menjadi surambi yang bermakna tinggal di rumah orang tua sendiri, tetapi tidak dalam mandiri baik dari segi finansial maupun kehidupan sehari-hari.

Infiks - al- sebagaimana infiks yang lain tidak produktif dan hanya muncul pada kata-kata tertentu saja. Oleh sebab itu, makna harus mengacu pada kata yang dilekatinya. Infiks ini ditemukan pada dua contoh berikut ini.
susur + al
$=$ salusur
sisit + al
$=$ salisit

Kata susur bermakna menyisir atau menjelajahi. Setelah dibentuk dengan infiks -almenjadi salusur. Kata sisit bermakna menarik, tetapi setelah dibentuk dengan infiks -al-menjadi salisit. Makna yang muncul menjadi kegiatan bebek ketika membersihkan bulunya. 
Infiks -ul- menghasilkan makna kegiatan yang lebih spesifik dari makna awal kata dasar. Contoh pembentukan ini adalah sebagai berikut.

$\begin{array}{ll}\text { kacak }+\mathrm{ul} & =\text { kulacak } \\ \text { kulik }+\mathrm{ul} & =\text { kulilik } \\ \text { kupak }+\mathrm{ul} & =\text { kulipak }\end{array}$

Kata-kata dasar yang disebutkan awalnya bersifat umum. Namun, setelah dibentuk dengan infiks -ul- makna kata yang terkandung di dalamnnya berubah menjadi lebih spesifik. Kata kacak bermakna memegang, tetapi setelah dibentuk menjadi kulacak menghasilkan makna mencakar atau memegang dengan perasaan marah. Kata kulik bermakna memperhatikan, tetapi setelah dibentuk dengan infiks -ul- menjadi kulilik yang bermakna memperhatikan dengan sembunyi-sembunyi. Begitu juga kata kupak bermakna mengupas, setelah berubah menjadi kulipak menjadi kulit buah atau kulit pohon.

\section{Sufiks Infleksional Verba}

Sufiks infleksional verba yang ditemukan dalam bahasa Banjar hanya satu, yakni -akan. Sufiks ini bermakna melakukan sesuatu untuk orang lain. Kata yang dibentuk melalui sufiks ini bersifat direktif. Pembentukan ini dapat dilihat pada contoh berikut ini.

$\begin{array}{lll}\text { gugur }+ \text { akan } & =\text { gugurakan } & \\ \text { ambil }+ \text { akan } & =\text { ambilakan } & \text { (ambilkan) } \\ \text { timbay }+ \text { akan } & =\text { timbayakan } & \text { (lemparkan) }\end{array}$

\section{Konfiks Infleksional Verba}

Konfiks infleksional dalam bahasa Banjar tampaknya merupakan pengembangan dari prefiks infleksional. Konfiks menghasilkan makna yang lebih spesifik atas tindakan dari kata yang dilekatinya. Konfiks infleksional bahasa Banjar berjumlah enam buah, yaitu ma-an, ma-i, ma-akan, ta-an, ta-i, dan ta-akan. Adapun imbuhan gabung yang merupakan pengembangan konfiks-konfiks itu berjumlah dua, yaitu mai-i-akan dan ta-i-akan. Meskipun demikian, bila dicermati konfiks dan imbuhan gabung ini dapat diklasifikasikan menjadi dua jenis, yakni afiksasi yang menghasilkan makna perbuatan yang disengaja, yakni ma-an, ma-i, ma-akan, dan mai-i-akan, serta afiksasi yang menghasilkan makna perbuatan yang tidak disengaja, yaitu ta-an, ta-i, ta-akan, dan ta-i-akan.

Konfiks menghasilkan makna perbuatan yang lebih rinci dibandingkan prefiks atau sufiks. Konfiks ma-an menghasilkan makna melakukan sesuatu bersama-sama. Misalnya $M a+t u k a r+a n$ menjadi manukaran yang berarti membeli bersama-sama. Bila perbuatan dilakukan berulang-ulang konfiks yang digunakan ialah $m a-i$, seperti $m a+c a t u k+i$ menjadi mancatuki yang menghasilkan makna memukuli berlang-ulang. Adapun ketika perbuatan itu dilakukan untuk orang lain, konfiks 
yang digunakan ialah ma-akan. Misalnya, ma + tabuk + akan menjadi manabukakan yang berarti menggali untuk orang lain.

Kombinasi afiks-afiks ini menghasilkan imbuhan gabung ma-i-akan yang merupakan gabungan dari beberapa afiks dalam bahasa Banjar, yaitu sufiks $-i$, prefiks $m a-$, kemudian sufiks akan. Imbuhan ini hanya muncul pada proses infleksional pada lingkup verba. Pembentukan infleksional ini merupakan gabungan dari afiks-afiks tersebut. Sufiks $-i$ bermakna perintah, prefiks $m a$ - bermakna melakukan, dan sufiks -akan bermakna melakukan untuk orang lain. Dengan demikian, makna yang muncul ialah perintah untuk melakukan sesuatu untuk orang lain. Misalnya, kalimat "Inya manimbayiakan kunci ka subalah" berarti dia melemparkan kunci untuk orang lain ke sebelah.

Makna perbuatan tidak sengaja yang dihasilkan beberapa konfiks bahasa Banjar tidak jauh berbeda dengan kategori sebelumnya. Konfiks ta-an menghasilkan makna perbutan tanpa sengaja dalam jumlah yang banyak. Misalnya, $\mathrm{t} a+$ gugur + an menjadi taguguran menghasilkan makna berjatuhan Bila konfiks ta-an menghasilkan makna ketidaksengajaan berulang yang acak, konfiks ta-i kesengajaannya berfokus pada suatu objek. Misalnya, pada kalimat "Buahnya taguguran" bermakna buah yang jatuh tanpa sengaja jatuh begitu saja secara acak. Namun, pada kalimat "Mun mamutik buah jangan taguguri rumah orang" bermakna bila memetik buah jangan sampai menjatuhkannya tanpa sengaja ke rumah orang.

Adapun konfiks ta-akan menghasilkan makna perbuatan tanpa sengaja kepada orang lain. Pada kalimat "Parang yang ikan pinjam samalam tabulikakan lawan sidin sudah" maknanya ialah parang yang kamu pinjam kemarin tanpa sengaja sudah aku kembalikan kepada pemiliknya.

Kombinasi afiks-afiks ini menghasilkan imbuhan gabung ta-i-akan yang berpola sama dengan imbuhan gabung ma-i-akan yang telah dibahas sebelumnya. Prefiks ta- bermakna melakukan sesuatu tanpa sengaja, sufiks $-i$ bermakna perintah untuk melakukan sesuatu, dan sufiks -akan yang bermakna melakukan untuk orang lain.

Berbeda dengan sebelumnya, imbuhan gabung ini dapat berasal dari dua kemungkinan tahapan. Versi pembentukan yang pertama sama dengan ma-i-akan yang telah dibahas, yaitu dimulai dari sufiks $-i$, kemudian prefiks $t a$-, dan diakhiri sufiks -akan. Versi yang kedua pembentukannya berasal dari konfiks ta-i dan sufiks - akan.

Ada dua konsekuensi pemaknaan yang berbeda dari dua versi ini. Perbedaan itu muncul pada tahap awal. Versi pertama memunculkan makna secara bertahap, yakni memerintahkan melakukan sesuatu, kemudian tindakan tanpa sengaja, sedangkan versi yang kedua langsung menghasilkan makna melakukan sesuatu tanpa sengaja. Misalnya, kata tatukariakan versi pertama berbentuk seperti ini:
tukar $+\mathrm{i}$
$=$ tukari
(belilah) 


$$
\begin{array}{lll}
\text { ta }+ \text { tukar }+\mathrm{i} & =\text { tatukari } & \text { (terbeli) } \\
\text { ta }+ \text { tukar }+\mathrm{i}+\text { akan } & =\text { tatukariakan } & \text { (tanpa sengaja membelikan orang) }
\end{array}
$$

Versi kedua langsung dimulai dengan konfiks ta-i dengan makna yang sama. Begitu juga setelah dilekati sufiks -akan makna yang muncul cenderung sama, yaitu tindakan dilakukan untuk orang lain.

\section{B. Pembentukan Infleksional dalam Lingkup Nomina}

Pembentukan infleksional dalam lingkup nomina bahasa Banjar yang ditemukan dalam penelitian ini berjumlah enam buah, yaitu prefiks 2 buah, konfiks 3 buah, dan imbuhan gabung 1 buah. Pembahasan mengenai pembentukan ini adalah sebagai berikut.

\section{Prefiks Infleksional Nomina}

Prefiks infleksional pada lingkup nomina dalam bahasa Banjar yang berhasil ditemukan ada dua, yaitu $p a$ - dan $s a$-. Prefiks $p a$ - menghasilkan makna orang yang melakukan. Misalnya, $p a+$ gargaji menjadi panggargaji yang berarti orang yang menggergaji. Adapun prefiks $s a$ - menyatakan satu buah atau bersama dalam sesuatu. Pembentukan ini dapat diamati pada contoh berikut.

$$
\begin{array}{lll}
\mathrm{sa}+\text { kabat } & =\text { sakabat } & (\text { satu ikat }) \\
\mathrm{sa}+\text { batang } & =\text { sabatang } & \text { (satu batang) }
\end{array}
$$

\section{Konfiks Infleksional Nomina}

Konfiks infleksional nomina dalam bahasa Banjar yang berhasil ditemukan ada tiga buah, yaitu sa-an, ka-an, dan pa-an. Konfiks sa-an menghasilkan makna keseluruhan. Contoh yang menunjukkan hal ini adalah sebagai berikut.

$$
\begin{array}{lll}
\mathrm{sa}+\text { jukung }+ \text { an } & =\text { sajukungan } & \text { (keseluruhan perahu) } \\
\mathrm{sa}+\text { batangan }+ \text { an } & \text { = sabatangan } & \text { (keseluruhan batang) }
\end{array}
$$

Konfiks ka-an menghasilkan makna tidak cukup. Misalnya, pada kalimat "Kabanyakan saruan lalu ay kada kanasian" yang berarti terlalu banyak undangan sehingga nasinya tidak cukup. Konfiks pa-an dalam penelitian ini menghasilkan makna lokasi atau orang yang memiliki profesi tertentu. Makna lokasi terlihat pada kata, seperti pambanyuan yang berarti tempat air atau tempat mencuci, sedangkan makna profesi dapat ditemukan pada kata, seperti paiwakan yang berarti pencari ikan.

Imbuhan gabung lain yang berperan dalam pembentukan infleksional ditemukan pada sa-annya. Imbuhan gabung ini memiliki dua kemungkinan pembentukan. Kemungkinan pertama berasal dari gabungan prefiks sa-, sufiks - an, dan sufiks -nya. Misalnya, kata bungkus menjadi sabungkus, sabungkusan, dan sabungkusannya. Tahap pembentukannya adalah sebagai berikut.

$$
\begin{array}{lll}
\mathrm{sa}+\text { bungkus } & =\text { sabungkus } & \text { (sebungkus) } \\
\mathrm{sa}+\text { bungkus }+ \text { an } & =\text { sabungkusan } & \text { (sebungkus penuh) }
\end{array}
$$


$\mathrm{sa}+$ bungkus + an + nya $\quad=$ sabungkusannya (hanya sebungkus penuh)

Makna yang muncul dari pembentukan ini ialah dimulai dengan prefiks $s a$-, sufiks -an, dan sufiks -nya. Kemungkinan kedua imbuhan gabung ini berasal dari konfiks sa-an dan sufiks -nya. Makna yang muncul dari pembentukan ini menjadi satu bungkus penuh (sabungkusan) dan hanya satu bungkus penuh (sabungkusannya).

Namun, kemungkinan yang kedua lebih tepat daripada kemungkinan yang pertama. Pada kemungkinan pertama, pembentukan dengan prefiks $s a$ - pada kata dasar akan membentuk numeralia yang bermakna satu buah bila tidak diiringi dengan sufiks -an, sedangkan konfiks sa-an secara otomatis telah membentuk nomina yang berarti tidak mengubah kelas kata atau infleksional, sedangkan sufiks -nya hanya menjadi penekanan saja.

\section{Pembentukan Infleksional dalam Lingkup Adjektiva}

Penelitian ini menemukan ada 9 afiks yang berperan pada proses infleksional dalam lingkup adjektiva. Afiks yang dimaksud, yaitu 3 prefiks, 1 sufiks, dan 4 konfiks. Pembahasannya adalah sebagai berikut.

\section{Prefiks Infleksional Adjektiva}

Prefiks infleksional adjektiva dalam bahasa Banjar yang berhasil ditemukan ada tiga, yaitu $m a-$, ta-, dan $p a-$. Prefiks $m a-$ menghasilkan makna jamak dan menjadi. Makna jamak misalnya muncul pada kata mahabang yang berarti merah-merah. Makna ini sama ketika pembentukannya melibatkan kata warna yang lain, seperti mamutih, mahijau, manguning, dan seterusnya. Makna menghasilkan dapat diamati pada sifat mambungul (menjadi bodoh) atau mambukat (menjadi kental). Makna menjadi dalam pembentukan ini bukan tergolong verba, karena kata-kata tersebut menunjukkan perubahan sifat bukan tindakan. Misalnya, pada kalimat "Kalakuannya mambungul imbah bagana di Banjar” berarti perilakunya menjadi bodoh setelah tinggal di Banjar.

Prefiks $t a$ - dalam lingkup adjektiva menghasilkan makna lebih. Misalnya, kata ganal yang berarti besar menjadi taganal yang berarti lebih besar, kata pancau yang berarti tinggi menjadi tapancau yang berarti lebih tinggi, dan kata bungas yang berarti bagus menjadi tabungas yang berarti lebih bagus.

Prefiks $p a$ - dalam lingkup adjektiva menunjukkan sifat orang. Misalnya, kata koler yang bermakna sifat malas menjadi pangoler yang bermakna orang yang bersifat pemalas. Penggunaan kata ini terlihat pada kalimat "Ipul tuh dasar pangoler banar" yang berarti Ipul itu sangat pemalas. Kata pangoler dalam kalimat itu menunjukkan sifat dari orang yang bernama Ipul. Oleh sebab itu, kata pangoler masih tergolong adjektiva sehingga proses yang terjadi dalam pembentukan ini tergolong infleksional. 


\section{Sufiks Infleksional}

Sufiks infleksional dalam bahasa Banjar yang berhasil ditemukan hanya satu, yaitu -an. Masyarakat Banjar agak jarang menggunakan bentuk seperti ini pada kata sifat. Makna yang muncul dari pembentukan ini ialah perubahan kelas kata dasar yang awalnya tunggal menjadi jamak. Misalnya, kata ganal yang awalnya bermakna besar berubah menjadi ganalan yang bermakna besar-besar, seperti pada kalimat “Ayam ikam ganalan sudah” yang berarti ayam kamu sudah besar-besar.

\section{Konfiks Infleksional}

Konfiks infleksional dalam bahasa Banjar berjumlah empat buah, yaitu sa-an, pa-an, pa$n y a$, dan ka-an. Konfiks sa-an menyatakan intensitas sifat dari kata dasarnya. Makna yang muncul dari pembentukan ini ialah paling tinggi. Misalnya, kata sapanjangan pada kalimat "Sapanjangan jalan haur bapandir haja sidin" berarti sepanjang jalan beliau berbicara terus.

Konfiks pa-an sebelumnya telah ditemukan dalam proses infleksional pada lingkup nomina, tetapi maknanya agak berbeda ketika melekat pada adjektiva. Konfiks ini menghasilkan makna orang yang bersifat, seperti panakutan yang berarti orang yang bersifat penakut. Konfiks ini juga dapat menghasilkan makna jamak pada kata yang dilekatinya. Misalnya, pada kalimat "Bubuhannya pangoleran limbah gurunya kadada” berarti mereka menjadi pemalas setelah gurunya tidak ada.

Konfiks pa-nya menghasilkan makna superlatif, yakni sifat paling di antara perbandingan yang ada. Pada kalimat "Baju sidin pangganalnya” menyatakan bahwa baju milik beliau paling besar di antara baju-baju yang lain. Proses pembentukan infleksional konfiks pa-nya pada lingkup adjektiva dapat diamati pada contoh berikut.

$$
\begin{array}{lll}
\mathrm{pa}+\text { ganal }+ \text { nya } & =\text { pangganalnya } & \text { (paling besar }) \\
\mathrm{pa}+\text { anum }+ \text { nya } & =\text { paanumnya } & \text { (paling muda })
\end{array}
$$

Pembentukan konfiks ka-an cukup sering terjadi dalam bahasa Banjar. Konfiks ini menghasilkan makna terlalu. Misalnya, kata handap berubah menjadi kahandapan, seperti pada kalimat "Tatakan ikam kahandapan" yang berarti potonganmu terlalu pendek. Kata panjang berubah menjadi kapanjangan, seperti pada kalimat "Bajuku kapanjangan tangannya” yang berarti bagian lengan bajuku terlalu panjang. Begitu juga dengan kata lamak berubah menjadi kelamakan, seperti pada kalimat “Awak ikam kalamakan sudah, mun sawat kaganalan ngalih mancari baju”. Kalimat ini berarti tubuhmu sudah terlalu gemuk, bila sudah terlalu besar sulit mencari baju. Simpulan

Pembentukan infleksi dalam morfologi bahasa Banjar terjadi melalui pembentukan afiks dengan kata dasar. Afiks dapat berasal dari prefiks, infiks, sufiks, konfiks, atau imbuhan gabung. Meskipun tidak mengubah kelas kata, proses infleksional dalam bahasa Banjar selalu 
mengakibatkan perubahan makna. Afiks yang melekat pada kata dasar menentukan makna yang muncul setelah perubahan terjadi.

Pembentukan infleksional dalam bahasa Banjar terbagi menjadi tiga, yaitu pembentukan pada lingkup verba, nomina, dan adjektiva. Ketiganya selalu melibatkan prefiks dan konfiks, tetapi sufiks tidak pernah muncul pada lingkup nomina, sedangkan infiks hanya muncul dalam lingkup verba. Pembentukan infleksional pada lingkup verba terdiri dari prefiks berjumlah 5 buah, sufiks 1 buah, infiks 4 buah, konfiks 6 buah, dan imbuhan gabung 2 buah. Pada lingkup nomina pembentukan infleksional terdiri dari prefiks 2 buah, konfiks 3 buah dan, imbuhan gabung 1 buah. Adapun pada lingkup adjektiva 9 afiks yang berperan dalam proses infleksional, yaitu 3 prefiks, 1 sufiks, dan 4 konfiks.

\section{Daftar Rujukan}

Ermanto. 2008. Perspektif morfologi derivasional dan infleksional pada verba berafik bahasa Indonesia. Kajian Linguistik dan Sastra, Vol. 20, No. 1, Juni 2008: 24-37, (online) (https://publikasiilmiah.ums.ac.id/bitstream/handle/11617/169/3.\%20ERMANTO.pdf?seque nce=1\&isAllowed=y), diakses 3 Desember 2016 .

Hapip, Abdul Djebar. 2008. Tata Bahasa Banjar. Banjarmasin: CV. Aditama.

Kim, Say Young; Wang, Min; \& Ko, In Yeong. 2011. The processing of derivational morphology in korean-english bilingual readers. Bilingualism, vol 14 no 4: 473-488. (online), (doi:http://dx.doi.org/10.1017/S1366728910000477), diakses 3 Desember 2016.

Kirkici, Bilal \& Clahsen, Harald. 2013. Inflection and derivation in native and non-native language processing: Masked priming experiments on turkish. Bilingualism, vol 16 no 4: 776-791. (online), (doi:http://dx.doi.org/10.1017/ S1366728912000648), diakses 3 Desember 2016.

Kridalaksana, Harimurti. 2011. Kamus Linguistik. Jakarta: PT Gramedia Pustaka Utama.

Mantra, I Ketut; Budasi, I Gede; Suarnajaya, I Wayan. 2013. An analysis of derivational and inflectional morphemes in Nusa Penida dialect. PRASI, vol 8, no 16 Juli - Desember 2013: 4-12.

Purnanto, Dwi. 2006. Kajian morfologi derivasional dan infleksional dalam bahasa Indonesia. Kajian Linguistik dan Sastra, vol. 18, no 35, 2006: 136-152, (online), (https://publikasiilmiah.ums.ac.id/bitstream/handle/11617/217/5.\%20DWI\%20PURNANTO .pdf?sequence=1\&isAllowed=y), diakses 3 Desember 2016.

Ramsi, Ida Satriyani Kasran. 2017. Infleksi dalam Bahasa Kulisusu. Jurnal Bastra, vol 1 no 4, Maret 2017: 1-8.

Riani. 2012. Penanda Jamak Infleksi dalam Bahasa Sunda. Widyaparwa, vol 40, no 2, Desember 2012: 39-48. 
Samingin, FX. 2006. Morfologi Infleksional dan Derivasional dalam Proses Morfologi Bahasa Indonesia. vol. 26, no 2, 15 September 2006 (13): 360-377. (online) (http://jurnal.utm.ac.id/index.php/jpi/article/viewFile/135/ 133), diakses 3 Desember 2016.

Widyanti, Erni; Wibisono, Bambang; \& Sofyan, Akhmad. 2013. Derivasi dan Infleksi dalam Bahasa Jawa pada Majalah Panjebar Semangat. Universitas Jember. 